\title{
PELATIHAN INTERVENSI GANGGUAN KESULITAN BELAJAR DAN GANGGUAN PSIKOLOGIS RINGAN BAGI GURU DI GUGUS II GIRIKERTO
}

\author{
THE TRAINING OF INTERVENTION ON LEARNING DIFFICULTIES AND MILD \\ PSYCHOLOGICAL DISORDERS FOR TEACHERS IN GUGUS II GIRIKERTO
}

\author{
${ }^{1)}$ Laila Fatmawati, ${ }^{2}$ Siti Urbayatun, ${ }^{3)}$ Vera Yuli Erviana, ${ }^{4)}$ Ika Maryani \\ ${ }^{1,3,4)}$ Program Studi Pendidikan Guru SD, ${ }^{2}$ Program Studi Psikologi \\ Universitas Ahmad Dahlan \\ Jalan Ki Ageng Pemanahan Nomor 19, Sorosutan, Umbulharjo, Yogyakarta
}

Email: laila.fatmawati@pgsd.uad.ac.id

\begin{abstract}
ABSTRAK
Banyak faktor yang menyebabkan siswa mengalami gangguan kesulitan belajar. Salah satunya yaitu gangguan psikologis ringan. Selama ini masalah gangguan kesulitan belajar siswa di Gugus II Girikerto ini belum ditangani dengan maksimal. Hal ini dikarenakan pengetahuan guru di Gugus II Girikerto dalam mengidentifikasi gangguan kesulitan belajar siswa dan merencanakan bentuk intervensi masih relatif minim. Program pelatihan ini bertujuan untuk meningkatkan pengetahuan guru dalam mengidentifikasi gangguan kesulitan belajar, gangguan psikologis ringan, serta merencanakan program intervensinya. Metode yang dilaksanakan dengan pelatihan yang bersifat problem based learning dengan mengangkat masalah kontekstual. Hasil pelatihan antara lain: pertama, hasil rerata angket self evaluation sebesar 67,55. Sebanyak 21 (66\%) guru memiliki kemampuan mengatasi kesulitan belajar siswa di atas rerata, dan sisanya 11 (34\%) guru memiliki kemampuan mengatasi kesulitan belajar siswa di bawah rerata. Kedua, guru mampu mengidentifikasi ganggun psikologis ringan melalui panduan skrining gejala gangguan psikologis. Ketiga, guru mampu merancang bentuk intervensi gangguan kesulitan belajar melalui metode token economy. Secara umum dapat disimpulkan bahwa pelatihan ini mampu meningkatkan pemahaman dan keterampilan guru di Gugus II Girikerto mengenai intervensi gangguan kesulitan belajar yang disebabkan oleh gangguan psikologis ringan pada siswa SD.
\end{abstract}

Kata kunci: Intervensi; Kesulitan belajar; Gangguan psikologis ringan

\begin{abstract}
Many factors cause students to experience learning difficulties. One of them is mild psychological disorders. Student learning difficulties problem in Gugus (cluster) II Girikerto has not been dealt with optimally. This was because, in the Gugus II Girikerto, the teachers' knowledge in identifying student learning difficulties and planning for interventions was still minimal. This training program aimed to increase teachers' experience in identifying learning difficulties, mild psychological disorders, and planning intervention programs. The training implemented the problem-based learning method by raising contextual issues. The training results are first; the average effect of the self-evaluation questionnaire was 67.55. A total of $21(66 \%)$ teachers can overcome students' learning difficulties above the average, and the remaining 11 (34\%) teachers can overcome students' learning difficulties below the average. Second, the teachers can identify mild psychological disorders through the guidance of screening for mental disorders symptoms. Third, the teachers can design a form of intervention for learning difficulties disorders through the token economy method. In general, it can be concluded that this training can increase the understanding and skill of teachers in Gugus II Girikerto regarding interventions for learning disabilities caused by mild psychological disorders in elementary students.
\end{abstract}

Keywords: Intervention; Learning Difficulty; Mild Psychological Disorders

Submitted : 15 Oktober 2019 Revision : 1 November 2019 Accepted : 17 Februari 2020 


\section{PENDAHULUAN}

Belajar merupakan proses interaksi edukatif yang terjalin antara guru dan siswa. Keberhasilan proses belajar ditandai dengan tercapai tujuan pembelajaran yang telah direncanakan sebelumnya serta siswa mampu memperoleh hasil belajar yang maksimal (Handayani, Manuaba, \& Ganing, 2014).

Keberhasilan proses belajar dipengaruhi oleh berbagai factor baik internal maupun eksternal. Selain itu siswa sebagai individu yang khas juga memiliki keunikan sendiri dalam belajarnya, ada siswa yang dapat merespon pembelajaran dengan cepat dan ada juga yang lambat (Rijal \& Bachtiar, 2015).

Harapannya semua siswa dapat merespon pembelajaran dengan cepat, namun kenyataan di lapangan masih sering dijumpai siswa yang lambat dalam merespon pembelajaran. Hal ini ditunjukkan dengan pencapaian prestasi akademik yang kurang memuaskan atau belum terpenuhinya criteria ketuntasan minimum yang ditetapkan sekolah. Problem ini yang sering dikenal dengan istilah kesulitan belajar.

Kesulitan belajar diartikan sebagai ketidakmampuan siswa dalam menerima materi pelajaran dengan baik. Siswa yang mengalami kesulitan belajar berada dalam kondisi dia tidak mampu mencapai hasil belajar sesuai dengan standar yang telah ditetapkan baik dalam pencapaian hasil akademik maupun aktivitas harian (Janurti, Dibia, \& Widiana, 2016).

Kesulitan belajar yang umum dijumpai pada siswa SD yaitu kesulitan membaca, menulis dan berhitung. Kesulitan membaca cepat ditandai dengan siswa kurang fasih dalam membaca (masih terbata-bata), menggunakan jari tangan untuk menunjuk tiap kata yang dibaca, masih lamban dalam membaca, masih sulit memahami isi bacaan, bergumam saat membaca, pikiran tidak focus pada bacaan, kepala ikut bergerak saat membaca (Janurti, Dibia, \& Widiana, 2016). Kesulitan membaca paling banyak dialami pada siswa SD kelas rendah $(1,2$, dan 3$)$. Terdapat $85 \%$ siswa SD kelas awal yang diindikasikan mengalami kesulitan membaca (Jamaris, 2009).

Keterampilan membaca erat kaitannya dengan keterampilan menulis. Biasanya siswa yang mengalami kesulitan membaca cenderung memiliki kesulitan menulis. Kemampuan membaca dan menulis siswa di Indonesia masih tergolong rendah dari hasil PISA dan PIRLS (Kharizmi, 2019). Kesulitan berhitung atau matematika juga menempati urutan atas penyebab rendahnya nilai siswa di SD. Karakteristik siswa dengan kesulitan belajar matematika antara lain: (1) adanya gangguan dalam konsep hubungan keruangan seperti atasbawah, depan-belakang, jauh-dekat, (2) abnormal dalam persepsi visual sehingga tidak mampu membedakan bentuk-bentuk geometri, (3) asosiasi visual-motor yaitu tidak bias menghitung benda-benda secara berurutan, (4) perserverasi atau perhatian yang melekat pada satu objek dalam jangka waktu lama, (5) kesulitan memahami symbol matematis, (6) performa IQ rendah dari pada verbal IQ (Murtadlo, 2013).

Faktor penyebab gangguan kesulitan belajar secara garis besar dibagi menjadi dua yaitu factor eksternal dan internal. Faktor eksternal meliputi lingkungan social siswa seperti lingkungan keluarga, lingkungan masyarakat, dan lingkungan sekolah. Sedangkan faktor internal meliputi factor fisiologis yang berhubungan dengan kondisi fisik dan kesehatan serta factor psikologis yang berhubungan dengan motivasi internal, tingkat intelegensi, minat dan bakat. Faktor psikologis penyebab kesulitan belajar menempati persentase $75 \%$, dimana siswa merasa tidak termotivasi dalam mengerjakan soal-soal yang sulit. Dapat ditarik kesimpulan bahwa factor psikologis mampu memunculkan kesulitan belajar (Pangestika, 2016).

Dampak yang ditimbulkan apabila kesulitan belajar tidak tertangani dengan baik yaitu mengganggu siswa dalam menerima pengetahuan baru, semakin bertumpuknya materi yang tidak dikuasai, kesulitan mengerjakan soal-soal evaluasi dan pada akhirnya hasil belajar menjadi rendah(Alawiyah, Muldayanti, \& Setiadi, 2016). Lebih lanjut, ternyata kesulitan belajar siswa berdampak negatif pada kondisi psikologis siswa mencakup konsep diri, penghargaan diri, dan motivasi belajar. Konsep diri yang rendah menyebabkan motivasi belajar menjadi rendah, dan lama kelamaan siswa menjadi tidak menghargai dirinya sendiri (Rudiyati, Pujaningsih, \& Ambarwati, 2010).

Siswa dengan gangguan kesulitan belajar kerap menunjukkan gangguan psikologis seperti sulit berinteraksi dengan temannya 
terutama saat bekerja kelompok, sikap agresif dan mudah tersinggung, pemurung, menunjukkan sikap tak wajar seperti menentang, membolos, tidak mengerjakan tugas, tidak tertib dan membuat kegaduhan di kelas(Yeni, 2015).

Jika hal ini dialami secara terus menerus dapat membuat siswa lebih mudah berpikir irrasional, takut, cemas, phobia bahkan membenci mata pelajaran tertentu. Jika dibiarkan terus menerus dikhawatirkan hambatan tersebut akan melekat pada diri siswa (Sutrisno, 2015).

Berdasarkan uraian tersebut dapat ditarik benang merah antara kesulitan belajar dan gangguan psikologis pada siswa SD. Untuk menyelesaikan masalah tersebut guru dituntut untuk peka dan tanggap terhadap kesulitan belajar siswanya. Guru perlu memiliki pengetahuan tentang karakteristik dan factor pemicu kesulitan belajar siswa dan dampaknya terhadap gangguan psikolgis. Dengan demikian guru dapat memberikan intervensi yang tepat dalam menangani masalah kesulitan belajar siswanya (Pangestika, 2016).

Kondisi ini menjadi dilematis bagi guru. Di satu sisi guru memiliki tanggungjawab penuh mengantarkan siswanya meraih prestasi gemilang, namun di sisi lain guru masih kesulitan menangani siswa dengan gangguan kesulitan belajar. Guru tidak memiliki latar belakang akademis yang memberikan bekal mendalam tentang penanganan anak berkebutuhan khusus. Hampir semua guru kelas di SD mengalami hal serupa. Mereka terlalu banyak memberikan toleransi kepada siswa yang mengalami gangguan kesulitan belajar yang sulit disembuhkan khususnya anak-anak berkebutuhan khusus (Rudiyati, Pujaningsih, \& Ambarwati, 2010).

Problem serupa juga dialami oleh guruguru di Gugus II Girikerto yang terletak di Desa Girikerto, KecamatanTuri, Sleman, DIY. Gugus II Girikerto merupakan perkumpulan SD segugus Girikerto yang terdiri dari 5 SD yaitu SD Muhammadiyah Girikerto, SD Negeri Soprayan, SD Negeri Somoitan, SD Negeri Sukorejo, dan SD Negeri Kloposawit. Hasil observasi menunjukkan bahwa kondisi sosial ekonomi masyarakat sekitar membawa pengaruh pada iklim akademik di sana. Penduduk setempat mayoritas memiliki mata pencaharian sebagai petani di kebun salak atau penambang pasir di sekitar lereng Merapi. Kesibukan mengelola lahan pertanian dan menambang membuat jalinan kerjasama antara sekolah dan wali murid menjadi kurang optimal dalam mengawasi perkembangan akademik anaknya.

SD di Gugus II Girikerto bukan termasuk SD inklusi, namun ada beberapa siswa ABK yang bersekolah di sana dengan alasan jarak yang dekat dengan lingkungan tempat tinggal. Hal ini menyebabkan siswa ABK tersebut tidak dapat menerima perlakuan istimewa dari sekolah. Kasus yang banyak terjadi yaitu masih banyak siswa yang sebenarnya tidak tuntas KKM terutama untuk pelajaran berhitung, membaca dan menulis. Bagi siswa kelas tinggi sains dan matematika menjadi pelajaran yang dianggap sulit.

Di kasus lain yaitu ada beberapa siswa yang menunjukkan sikap menentang seperti tidak menaati peraturan, membolos saat jam pelajaran, sikap agresif dan mudah marah, serta sering membuat gaduh saat pelajaran berlangsung. Hal ini diindikasikan sebagai salah satu gejala gangguan psikologis ringan.

Masalah gangguan kesulitan belajar dan gangguan psikologis ringan di Gugus II Girikerto belum dapat terselesaikan dengan maksimal. Pemicunya yaitu masih kurangnya keterampilan guru dalam melakukan diagnostic gangguan kesulitan belajar serta belum adanya pendampingan dari ahli (psikolog) dalam memberikan program intervensi yang tepat bagi siswa dengan gangguan psikologis ringan.

Sebetulnya guru-guru di Gugus II Girikerto memiliki semangat yang besar untuk terus belajar, hal ini terbukti dari kegiatan KKG yang rutin dilakukan setiap bulan. KKG biasanya diisi dengan pelatihan-pelatihan untuk meningkatkan kompetensi guru, namun belum pernah dilakukan pelatihan menangani kasus bagi siswa. Untuk itu diperlukan pendampingan dari pakar berupa pelatihan intervensi gangguan kesulitan belajar dan gangguan psikologis ringan bagi guru di Gugus II Girikerto. Pelatihan ini bertujuan untuk meningkatkan keterampilan guru SD dalam melakukan intervensi untuk mengatasi gangguan psikologis ringan pada siswa SD yang berdampak pada kesulitan belajar akademik. 


\section{METODE}

Metode yang digunakan untuk menyelesaikan masalah mitra dalam hal ini adalah guru di Gugus II Girikerto adalah dengan mengadakan pelatihan. Peserta pelatihan berasal dari 5 SD yang tergabung di Gugus II Girikerto berjumlah 32 guru. Guru tersebar dari kepala sekolah, guru kelas, guru matematika, guru olah raga, dan guru agama.

Pelatihan dikemas dalam bentuk ceramah interaktif, praktek, dan problem based learning. Ceramah interaktif digunakan untuk memberikan pemahaman terkait konsep gangguan kesulitan belajar dan gangguan psikologis ringan. Selanjutnya diselingi praktek melakukan skrining gangguan psikologis ringan, dan menyajikan sejumlah kasus untuk dicoba dicari solusinya melalui diskusi kelompok.

Berdasarkan metode di atas, maka pelaksanaan program untuk mengatasi masalah mitra disajikan pada tabel 1 sebagai berikut :

Tabel 1. Pelaksanaan Pelatihan

\begin{tabular}{|c|c|c|}
\hline No. & $\begin{array}{l}\text { Hari/Ta } \\
\text { nggal }\end{array}$ & Materi/Kegiatan \\
\hline 1. & $\begin{array}{l}\text { Pelatihan } \\
1 \text { (20 Juli } \\
2019)\end{array}$ & $\begin{array}{l}\text { Konsep kesulitan belajar } \\
\text { siswa SD dan praktek } \\
\text { diagnostic GKB. }\end{array}$ \\
\hline 2. & & $\begin{array}{l}\text { Gangguan pemusatan } \\
\text { perhatian dan/hiperaktivitas }\end{array}$ \\
\hline 3. & $\begin{array}{l}\text { Pelatihan } \\
2 \text { (27 Juli } \\
2019)\end{array}$ & $\begin{array}{l}\text { Gangguan perkembangan } \\
\text { perilaku }\end{array}$ \\
\hline 4. & & $\begin{array}{l}\text { Praktik melakukan skrining } \\
\text { gangguan psikologis ringan }\end{array}$ \\
\hline 5. & $\begin{array}{l}\text { Pelatihan } \\
3 \text { (30 Juli } \\
2019)\end{array}$ & $\begin{array}{l}\text { Diskusi kelompok } \\
\text { membuat konsep tentang } \\
\text { token economy sebagai } \\
\text { metode intervensi gangguan } \\
\text { kesulitan belajar. }\end{array}$ \\
\hline
\end{tabular}

\section{HASIL DAN PEMBAHASAN}

Kegiatan pelatihan intervensi gangguan kesulitan belajar dan gangguan psikologis ringan diberikan kepada mitra yaitu guru di Gugus II Girikerto dengan tujuan meningkatkan pengetahuan dan keterampilan guru khususnya dalam mengidentifikasi gangguan kesulitan belajar dan gangguan psikologis ringan yang dialami siswanya serta mampu merancang konsep intervensi menggunakan media token economy.

Pelatihan pertama yaitu guru diberi pengetahuan materi konsep kesulitan belajar siswa. Peserta pelatihan diberikan materi lengkap tentang definisi kesulitan belajar, jenisjenis gangguan kesulitan belajar, factor penyebabnya.

Di akhir sesi peserta dibagi dalam 5 kelompok untuk berdiskusi tentang studi kasus yang diangkat dari masalah nyata yang ada di lapangan dengan nama siswa yang disamarkan. Dari hasil diskusi kelompok kasus nomer 1 disajikan kasus tentang siswa Bagas yang mengalami gangguan kesulitan belajar.

Secara garis besar jenis klasifikasi kesulitan belajar perkembangan (pra akademik) yang dicirikan dengan gangguan perkembangan motorik gerak dan perilaku yang usil, serta gangguan kesulitan belajar akademik dengan ditandai kesulitan membaca (disleksia), kesulitan menulis (disgrafia) kesulitan berhitung (diskalkulia). Factor penyebabnya dikarenakan disfungsiotak, genetic, malnutrisi dan factor biokimia. Hal tersebut akan berdampak pada ketidak mampuan menerima materi pelajaran dengan baik, dan menghasilkan nilai yang kurang maksimal bagi siswa dengan GKB. Bagi teman-temannya tentu saja akan mengganggu sehingga konsentrasi belajar juga kurang maksimal, dan guru terhambat penyampaian materi. Perencanaan penanganan yang diberikan antara lain pengaturan tempat duduk anak di dekat guru, untuk kesulitan belajar membaca, diberi jam tambahan dengan tugas yang lebih banyak membaca begitu juga dengan kesulitan akademis yang lain, menjalin komunikasi dengan orangtua, mengundang psikolog, memberikan reward pada siswa bila menunjukkan perilaku positif, pembimbingan belajar dengan tutor sebaya dan home visit.

Guru perlu memiliki kemampuan melakukan diagnostic kesulitan belajar. Diagnostic sendiri diartikan sebagai usaha yang dilakukan untuk mengukur keadaan suatu kelompok sesuai dengan klasifikasi tertentu. Diagnostic kesulitan belajar berguna bagi guru agar guru dapat menentukan siswa mana yang masuk kedalam klasifikasi mengalami gejala kesulitan belajar dan mana yang tidak mengalami (Suwarto, 2013). Selain itu, dengan dilakukan diagnostic kesulitan belajar, dapat 
meminimalisir kesulitan belajar yang dialami siswa serta dapat memecahkan masalah yang dialami siswa lebih dini (Rahman, Sukifli, \& Hasyim, 2014).

Studi kasus selanjutnya, disajikan kasus siswa Galang dengan gejala AD/HD. Peserta telah mampu mengindentifikasi factor penyebab Galang mengalami gejala $\mathrm{AD} / \mathrm{HD}$ antara lain: (1) Faktor genetik ; sebagian anak kerjanya tidak benar, (2) kelahiran beratnya kurang dari 500 gram (prematur), (3) bayi kembar cenderung ke anak laki-laki, (4) makanan beracun, (5) Kultural psikososial.

Selanjutnya guru dapat menentukan problem yang dialami siswa Galang baik di rumah ataupun di sekolah. Problem di sekolah sulit memusatkan perhatian saat pelajaran, problem di rumah kurangnya perhatian dari orang tua dan terlalu banyak menonton TV, problem dari segi fisik (selalu bergerak), tidak pernah capek, sulit diminta tenang, problem dalam komunikasi (tidak pernah bisa diam), bahkan tersenyum sendiri. Dampak yang ditimbulkanya itu mengganggu suasana pembelajaran di kelas sehingga pembelajaran gaduh. Galang sulit menerima pelajaran serta guru kesulitan menangani gejala gangguan siswa Galang. Selanjutnya program penanganan siswa $\mathrm{AD} / \mathrm{HD}$ yang direncanakan yaitu: (1) dipisahkan dari anak yang lain yang tidak mengalami ADHD, (2) berkonsultasi dengan orangtua, (3) berkonsultasi dengan ahli / psikolog/dokter anak, (4) penanganan dalam hal pembelajarannya, misal : disediakan guru inklusi atau lanjut pada sekolah inklusi.

AD/HD dipilih sebagai salah satu kasus karena paling banyak gejala yang ditunjukkan pada siswa di SD Gugus II Girikerto yaitu kurangnya perhatian siswa saat belajar. $\mathrm{AD} / \mathrm{HD}$ merupakan salah satu jenis gangguan perkembangan meningkatnya aktivitas motorik yang terjadi pada anak sehingga anak tersebut memiliki aktivitas di atas rata-rata anak normal seusianya. Dalam perspektif pendidikan seorang anak $\mathrm{AD} / \mathrm{HD}$ memiliki kecenderungan mengalami kesulitan belajar, dan pada aspek psikologi social anak tersebut kesulitan dalam bersosialisasi dengan teman sebaya atau masyakarat serta mengalami kesulitan berperilaku (Ervinanaeni, Hidayat, \& Riana, 2019). Berikut disajikan gambar suasana diskusi kelompok.

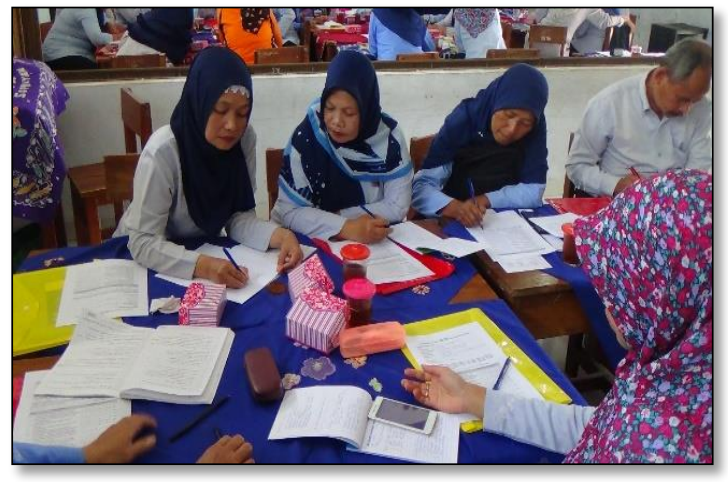

Gambar 1. Aktifitas diskusi kelompok

Setelah pelatihan pertama dilakukan pengukuran kemampuan guru dalam mengatasi kesulitan belajar siswa. Diberikan angket self evaluation. Pengukuran menggunakan metode one shoot case yaitu hanya mengukur hasil akhir kemampuan peserta setelah diberi treatment. Hasil rerata angket self evaluation sebesar 67,55. Sebanyak $21 \quad(66 \%)$ guru memiliki kemampuan mengatasi kesulitan belajar siswa di atas rerata, dan sisanya 11 (34\%) guru memiliki kemampuan mengatasi kesulitan belajar siswa di bawah rerata. Dapat disimpulkan bahwa pelatihan ini berhasil memberikan keterampilan baru bagi sebagian besar guru peserta pelatihan.

Pelatihan kedua peserta diberi pengetahuan tentang gangguan perkembangan yang umum dialami pada anak antara lain, gangguan perkembangan perilaku, pemusatan perhatian dan/hiperaktivitas, tuna laras, dan behavior dysregulation in children.

Di akhir sesi, peserta dilatih untuk melakukan skrining gangguan psikologis berbasis IT. Media panduan skrining gejala gangguan psikologis ringan dikembangkan oleh tim dengan bantuan software corel draw. Didalamnya berisi empat macam jenis gangguan yang sering muncul pada siswa. Berikut disajikan gambar contoh media panduanskrining yang telah dikembangkan oleh tim. 


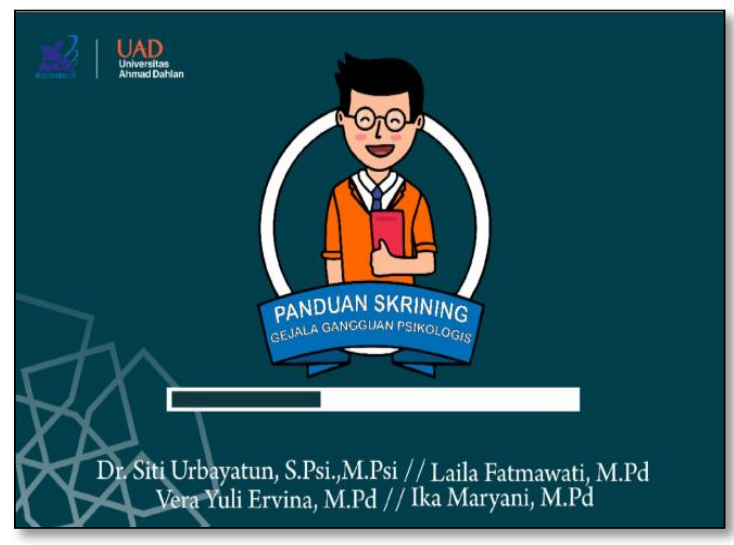

Gambar 2. Tampilan Cover Panduan

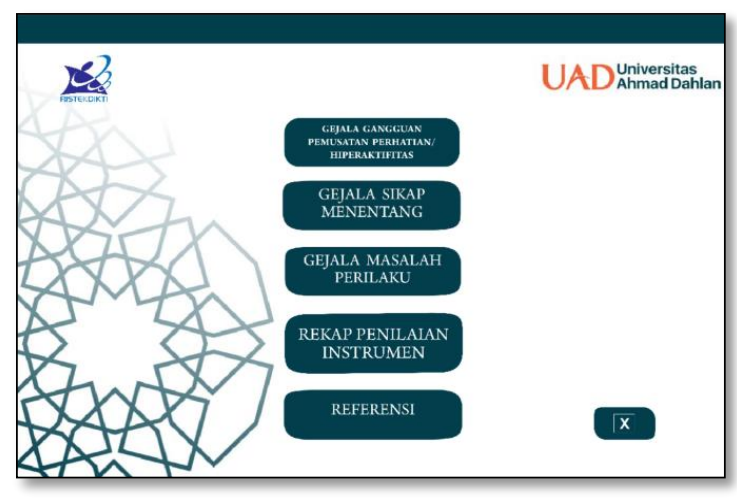

Gambar 3. Menu GangguanPsikologis

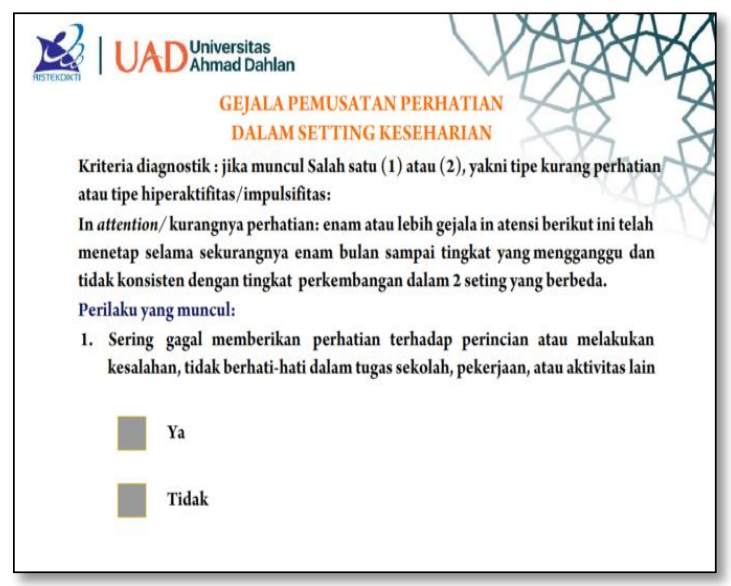

Gambar 4. Sampel Isi Media Berupa Gejala

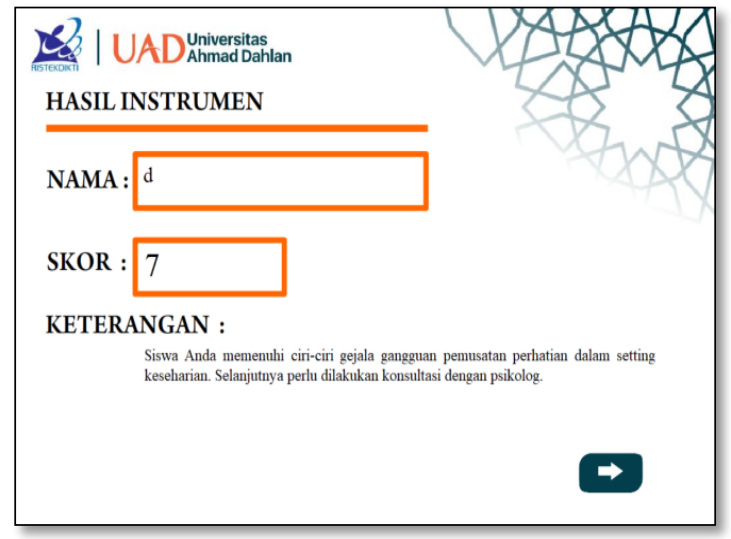

Gambar 5. Sampel Hasil Instrumen

Dalam menggunakan media panduan skrining gejala gangguan psikologis ringan sebaiknya guru tetap didampingi oleh pakar baik psikolog maupun dokter anak. Hal ini bertujuan agar guru tidak salah dalam melakukan diagnostic gejala. Peserta diminta untuk praktek mengoperasikan sendiri media panduan skrining tersebut dalam bentuk individu.

Pelatihan ketiga yaitu pemberian materi tentang metode token economy sebagai metode intervensi gangguan pada anak. Pada materi ini peserta dibagi menjadi 5 kelompok sesuai dengan asal SD. Masing-masing kelompok diminta untuk melakukan identifikasi kasus yang paling dominan muncul pada siswanya sendiri.

Selanjutnya kelompok diminta untuk merancang konsep token economy. Peserta terlihat kreatif dalam mengembangkan konsep token economy, ada yang berbentuk token avenger sesuai dengan kesukaan siswa sekarang, ada yang berbentuk champion. Kemudian token juga dirancang ada yang berupa piala, permen, tanda bintang, tanda super hero. Guru juga membuat back up reinforce yaitu semacam chart berisi reward untuk siswa apabila mencapai prestasi tertentu baik nilai ataupun sikap dalam jangka waktu yang telah disepakati bersama. Reward disesuaikan dengan hal-hal yang menarik bagi siswa di sekolah masing-masing. Selanjutnya masing-masing kelompok mempresentasikan hasil diskusinya di depan kelas, dan dilanjutkan sesi tanya jawab. 
Berikut juga dicantumkan gambar contoh token economy yang dikembangkan oleh tim bersama dengan guru setelah pelaksanaan selesai dilakukan.

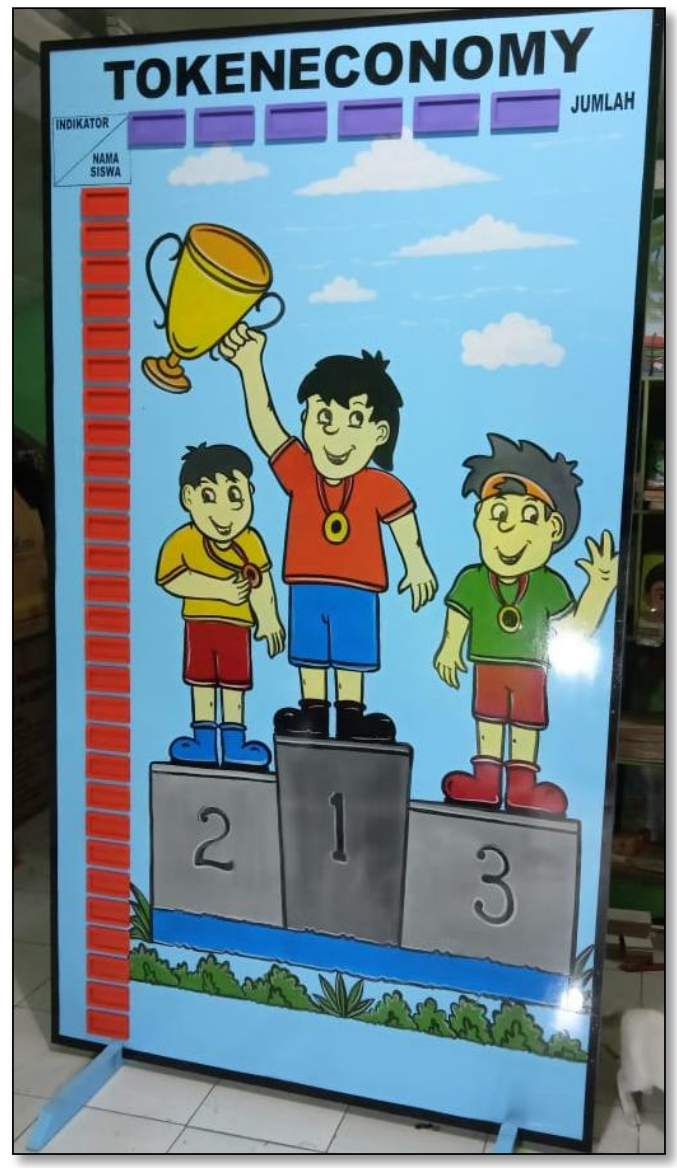

Gambar 6. Token Chart

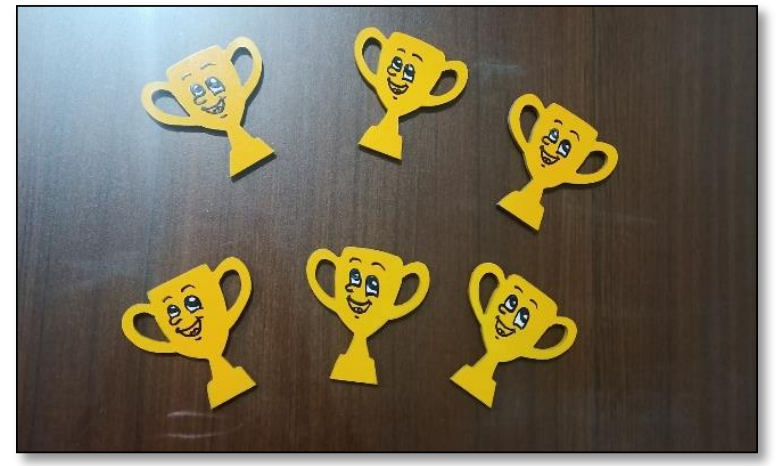

Gambar 7. Token coint
Token economy atau yang sering dikenal juga dengan tabungan koin merupakan suatu metode yang menggunakan prinsip conditioning reinforcement. Maksudnya yaitu siswa diberi stimulus jika dipasangkan dengan reinforce lainnya. Pemberian reinforcement dilakukan apabila siswa telah berhasil menunjukkan perilaku sesuai dengan yang diharapkan, misalnya tenang saat pelajaran, mempu menjawab pertanyaan guru dengan baik, tidak membuat gaduh di kelas, dan lain sebagainya (Indrijati, 2009).

Token ini seperti sistem barter, token yang telah dikumpulkan dapat ditukarkan dengan reward yang telah disepakati sebelumnya sesuai dengan kontrak bersama di awal sesi. Siswa yang berhasil menunjukkan perubahan perilaku dalam waktu tertentu dan berhasil mengumpulkan token coint dalam waktu tertentu maka dapat menukarkan dengan hadiah. Misalnya siswa mampu mengumpulkan 5 koin dalam seminggu apabila dia mematuhi peratutan, maka dia dapat menukarkan koinnya dengan hadiah berupa 1 buah coklat (Herliyanti, 2016).

Setelah selesai pelatihan dilakukan evaluasi respon peserta terhadap program pelatihan. Indikator evaluasi terbagi menjadi empat yaitu usefulness (kemanfaatan), ease of use (kemudahan pemakaian), ease of learning (kemudahan mempelajari), dan satisfaction (kepuasan). Empat indikator tersebut terbagi dalam 30 butir pertanyaan. Peserta diminta untuk memberikan skor 1: sangat tidak setuju, 2 : tidak setuju, 3 : setuju, dan 4 : sangat setuju.

Berikut disajikan diagram batang respon peserta pasca pelatihan.

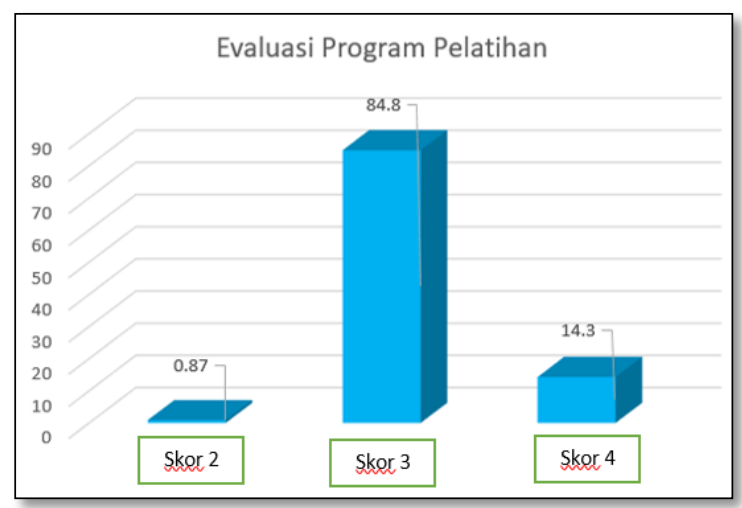

Gambar 8. Hasil Evaluasi Program Pelatihan 
Dari gambar diatas dapat diketahui bahwa sebanyak $0.87 \%$ peserta menjawab menjawab tidak setuju, mayoritas peserta sebesar 84,8\% memberikan skor 3 yang artinya setuju, dan sisanya sebesar $14,3 \%$ peserta menjawab sangat setuju bahwa pelatihan yang telah dilaksanakan bermanfaat, mudah digunakan mudah mempelajarinya dan peserta puas dengan pelatihan.

\section{SIMPULAN}

Program pelatihan intervensi gangguan kesulitan belajar dan gangguan psikologis ringan memberikan peningkatan pemahaman dan keterampilan peserta khususnya guru-guru SD di Gugus II Girikerto terkait keterampilan melakukan diagnostik gangguan kesulitan belajar, skrining gangguan psikologis ringan menggunakan media IT, dan perancangan konsep intervensi dengan metode token economi. Kegiatan tersebut perlu ada keberlanjutan program serupa di daerah-daerah lain agar terjadi pemerataan kemampuan guru dalam menangani anak-anak dengan gangguan psikologis ringan sehingga diharapkan gangguan kesulitan belajar dapat tereduksi.

\section{DAFTAR PUSTAKA}

Alawiyah, H., Muldayanti, N. D., \& Setiadi, A. E. (2016). Analisis Kesulitan Belajar Siswa dalam Memahami Materi Invertebrata di Kelas X MAN 2 Pontianak. Jurnal Biologi Education, 3(2), 9-20.

Ervinanaeni, Y., Hidayat, A. S., \& Riana, E. (2019). Sistem Pakar Diagnosa Gangguan Hiperaktivitas pada Anak dengan Metode Naive Bayes Berbasis web. Jurnal Media Informatika Budidarma, 3(2), 90-104.

Handayani, D. A., Manuaba, I. B., \& Ganing, I. N. (2014). Model Accelerated Learning Berbasis Eksperimen Berpengaruh terhadap Hasil Belajar IPA. Jurnal Mimbar PGSD Undiksha, 2(1).

Herliyanti, A. (2016). Teknik Token Economic Untuk Meningkatkan Kemampuan Kontak Mata Anak Autis. Jurnal Pendidikan Khusus, 9(1), 1-17.
Indrijati, H. (2009). Efektivitas Metode Modifikasi Perilaku "Token Economy" Dalam Proses Belajar Mengajar Di Kelas. Jurnal Psikologi Indonesia, 6(1), 43-54.

Jamaris. (2009). Kesulitan Belajar, Perspektif Assessmen Dan Penanggulangannya. Jakarta : Yayasan Pena Mas Murni.

Janurti, N. K., Dibia, I. K., \& Widiana, I. W. (2016). Analisis Kesulitan Belajar Dalam Pembelajaran Membaca Cepat Siswa Kelas V SD Gugus VI Kecamatan Abang. e-jurnal PGSD Undiksha, 4(1), 1-10.

Kharizmi, M. (2019). Kesulitan Siswa Sekolah Dasar Dalam Meningkatkan Kemampuan literasi. Jurnal Pendidikan Almuslim, 7(2), 94-102.

Murtadlo, A. (2013). Kesulitan Belajar (Learning Difficult) Dalam Pembelajaran Matematika. Jurnal EduMath, 4, 38-45.

Pangestika, N. S. (2016). Faktor-Faktor Kesulitan Belajar Siswa Berprestasi Rendah Di Kelas IV SD Negeri SeKecamatan Ngemplak. Jurnal Pendidikan Guru Sekolah Dasar, 8(5), 813-826.

Rahman, U., Sukifli, F., \& Hasyim, M. (2014). Kesulitan Belajar (Kasus Pada Siswa MI Madani Paopao Gowa). Jurnal Auladuna, 1(2), 218-228.

Rijal, S., \& Bachtiar, S. (2015). Hubungan antara Sikap, Kemandirian Belajar, dan Gaya Belajar dengan Hasil Belajar Kognitif Siswa. Jurnal BIOEDUKATIKA, 3(2), 15-20.

Rudiyati, S., Pujaningsih, \& Ambarwati, U. (2010). Penanganan Anak Berkesulitan Belajar Berbasis Akomodasi Pembelajaran. Jurnal Kependidikan, 40(2), 187-200.

Sutrisno. (2015). Analisis Kesulitan Belajar Siswa Kelas II Pada Materi Penjumlahan Dan Pengurangan Bilangan. Aksioma: Jurnal Matematika dan Pendidikan Matematika, 6(1), 113. 
Laila Fatmawati, Siti Urbayatun, Vera Yuli Erviana, Ika Maryani Pelatihan Intervensi Gangguan Kesulitan Belajar dan Gangguan Psikologis Ringan Bagi Guru di Gugus II Girikerto

Suwarto. (2013). Belajar Tuntas, Miskonsepsi, Dan Kesulitan Belajar. Jurnal Pendidikan, 22(1), 85-96.
Yeni, E. M. (2015). Kesulitan Belajar Matematika di Sekolah Dasar. Jupendas, 2(2), 1-10. 